\title{
Amo Amar
}

Recebido em 01-10-2020

Modificado em 27-01-2021

Aceito para publicação em 15-02-2021

\section{doi https://doi.org/10.47456/simbitica.v8i2.36388}

\section{Marcos Roberto dos Santos Amaral}

ORCID: 0000-0001-8130-4580

Doutorando em Linguística Aplicada pelo Programa de Pós-graduação em Linguística Aplicada da Universidade Estadual do Ceará (PosLA-UECE). Autor das poesias: Barata; A festa; By Serendipity; Esperançosos (Revista Berro); este reclama um heroi (Revista Desenredos); A rica muanbeira (Revista literalivre). E-mail: roberto.amaral@aluno.uece.br

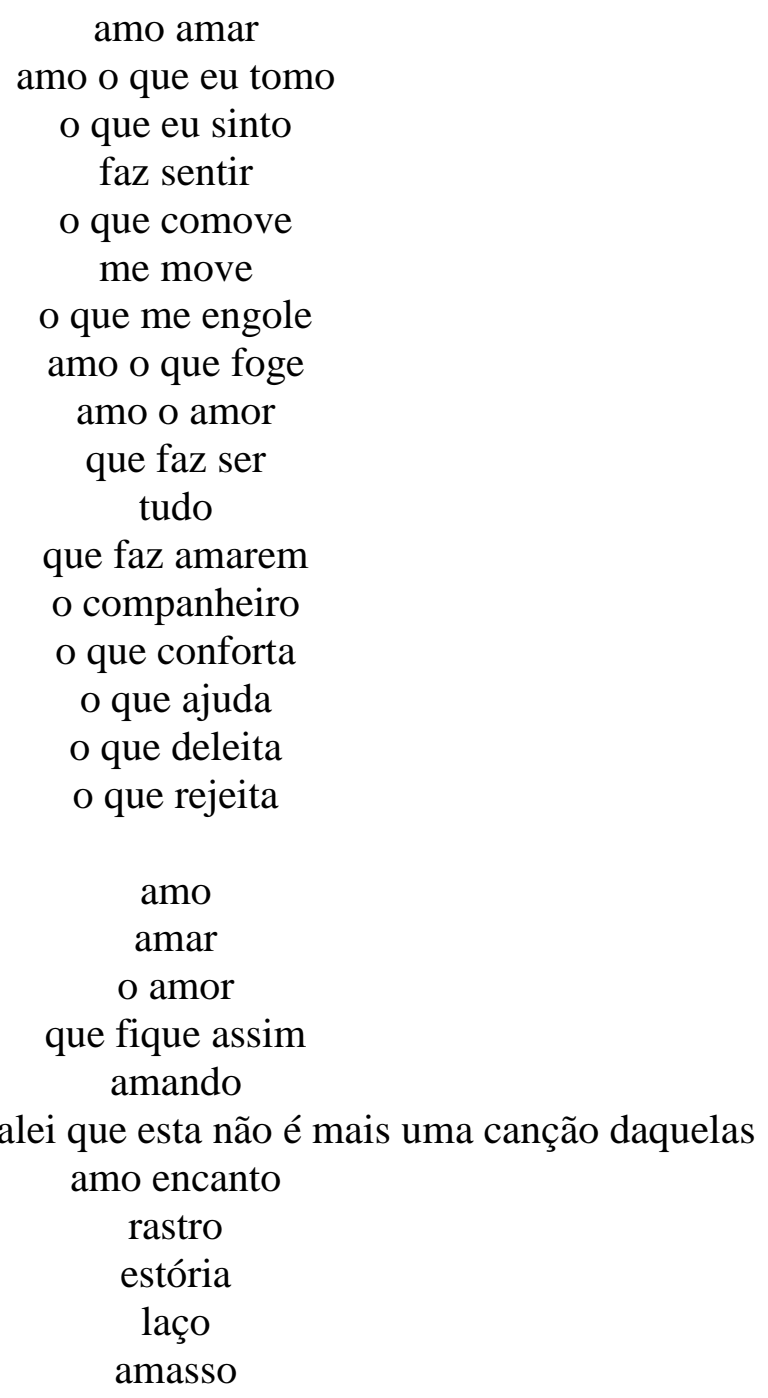




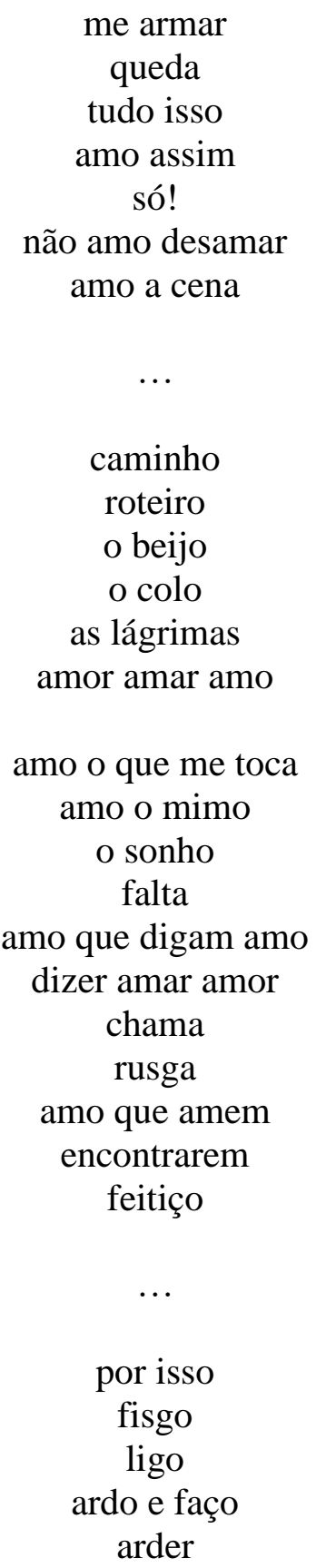

